\title{
Issues of increasing the professional competence of the head in the management of secondary education institutions
}

\author{
Kenesbaeva Elmira Zholdasbaevna ${ }^{1}$ \\ ${ }^{1}$ Assistant teacher at the Department of Pedagogy, \\ Nukus State Pedagogical Institute named after Ajiniyaz,Uzbekistan \\ Email:elmira123a@ umail.uz.
}

\begin{abstract}
The article focuses on the issues of improving the professional competence of the head in the management of secondary schools, discusses the qualities formed on the basis of the professional competence of the head, the professional competence of the head and their forms.
\end{abstract}

Keywords: managerial competence, professional competence, competence, competence, ability, innovative thinking, education system.

\section{INTRODUCTION}

The article focuses on improving the professional competence of managers in the management of secondary schools, the human factor, their role in society, creative thinking and making them the main tool. The author states in the article that a person's inner world has many undiscovered aspects, and addresses the professional and personal competence of the leader in the management of secondary education institutions in solving these problems. In explaining the content of the topic, each leader asked questions of interest to the staff and gave examples to prove it. It reflects the views of scholars who have conducted research on the subject.

\section{THE PURPOSE AND OBJECTIVES OF THE WORK}

All-round development of our republic depends on the level of personnel. Therefore, in the future, the need to train competent leaders in the management of the education system in accordance with the requirements of the Statute of Uzbekistan "On Education" and the "National Training Program" is one of the current issues. Today, the main indicators of the effectiveness of professionalism are not only the level of knowledge, experience or experience, but also the professional and personal competence of the leader, formed on the basis of their interaction.

\section{MAIN PART}

Here are the factors that connect competence with the leader, to make it clear that they are a living organism. Because while this clarity affects our next thoughts, it requires everyone to think a little. President Sh. Mirziyoyev said in a statement at an enlarged meeting of the Cabinet of Ministers on "The main results of socio-economic development of the country in 2016 and the main directions of the economic program for 2017": "Analysis, strong discipline and personal responsibility "Every leader, whether he or she is the Prime Minister or his or her deputies, members of the government or governors, heads of state institutions, should be the daily rule of their skill."

In fact, if we look at these views of our President, he set tasks that every leader has a great responsibility to the staff. The professional competence of the head in the management of general education institutions is very important for the process of managing the education system. This, in turn, requires not only separate knowledge, skills and practices from the leader, but also integrative knowledge in each independent direction, effective methods and tools of management, communication in management. Culture and assimilation of creative actions related to the service of leadership.

The meaning of competence, such as "one who knows well" and "one who has experience," has been explained many times in the ancient literature. Therefore, the different situations that occur in the process of competency training, how the leader behaves in unexpected situations, reactivity, the ability to understand the mental state of subordinates, a new way of dealing with competitors, Applying the acquired knowledge, skills and experience in solving existing problems on the basis of specific goals means having a plan of action in continuously evolving and complex processes. 
The concepts of "competence" and "competency" are being studied by many scholars. For example, according to N.A.Muslimov, Q.M.Abdullayeva, O.A.Qoysinov and other scholars: "A direct study of the content of education in foreign countries in the process of professional training of specialists shows that the level of competence experience plays a key role in the West countries. According to the content of the national education system of the Republic, the minimum requirements for the content of education are based on knowledge, skills and experience". [N.A.Muslimov: 8]

A.A.Verbisky and M.D.Ilyazova define these concepts as follows: "Competence is a system of goals, abilities, motives, personal qualities, knowledge, skills and experiences that enable a person to perform this or that service; competence is the competence of the person who has appeared and realized in practice, with the level of practical service and the development of social, moral qualities of the person".[S.Y.Temurov:8]

According to M.A. Kholodnaya, competence is: "Competence is a special type of subject selfknowledge, which allows you to make effective decisions in the appropriate service" [N.Muslimov: 8]

The glossary of the European Education Foundation gives a general meaning to the term: "Competence is-the ability to perform a task effectively, the ability to meet the requirements in the performance of work, the ability to meet the requirements for specific job functions" [A.A.Shayusupova:16].

Based on the above considerations and descriptions, the concept of competence can be defined as follows: It is a service that allows the community to follow in its footsteps, search for new information, process the collected data, and use it purposefully in its management service. Also, professional competence is the acquisition by a specialist of the knowledge, skills and experience necessary for the performance of professional services and their application in practice at a high level.

So, here in the management of general education institutions, based on the professional competence of the head, the following qualities are reflected:

1. Social competence - the ability to demonstrate skills in social relations, to have experience, to be able to interact with subjects in professional service.

2. Special competence - preparation for planning of professional and pedagogical service, rational solution of professional and pedagogical tasks, realistic assessment of service results. Based on this competence, psychological, methodological, informational, creative, innovative and communicative competence is observed.

psychological competence is - the ability of the head of the modern education system to create a healthy psychological environment during the implementation of the educational process, to form a positive relationship with teachers, other participants in the educational process, to understand and eliminate various unpleasant psychological problems in a timely manner;

$\checkmark \quad$ methodical competence is - methodologically effective and rational formation of the educational process, the correct definition of forms of teaching or educational services, the appropriate choice of methods and tools used in the pedagogical process, the effective use of teaching tools based on approaches, health creation of a spiritual pedagogical and psychological environment, the establishment of effective teaching;

$\checkmark \quad$ information competence is - the need for speed and communication in the message center, the search for the necessary, useful information for the learning process, the collection, separate sorting, processing and purposeful, appropriate, effective of them;

creative competence is - the ability to critically evaluate the work of teachers in the management of the educational process, the presence of a motivating factor for the quality of service in the community, the ability of the leader to educate himself;

$\checkmark \quad$ innovative competence is - the qualitative development of the educational process, the constant introduction of innovations that serve to improve the quality of education, the promotion of ideas related to improving the effectiveness of the educational process, their effective application in practice;

communicative competence is - pedagogical processing the ability to communicate openly with all participants, including teachers and students, to listen to them, to feel inner spiritual forgiveness, to understand their actions and interests, and to make a positive impact;

3. Personal competence - the ability to continuously achieve professional growth, increase the level of experience, to demonstrate their inner potential in professional service. 
4. Technological competence - mastery of advanced technologies, enrichment of professional and pedagogical skills, ability to use modern weapons, equipment and technologies.

5. Extreme competence is - the ability to make informed decisions and act appropriately in specific situations, such as when pedagogical problems arise.

The purpose of mentioning the professional competence of the head was not to show that education management has risen to the level of public policy in the current period, but to remind that the inner world of man, its many undiscovered aspects.

This is because old views are losing their relevance and new ones are emerging. After all, today requires a new way of thinking from each of us.

Innovative thinking is not about making the world look better. On the contrary, it means that we approach and evaluate the existing events with our own knowledge and thinking potential, based on the requirements of the time. Therefore, in the context of Uzbekistan's growing mass movement to build a civil, humane, democratic society, the rule of law, the only way to build and accelerate civil society is to equip the innovative thinkers who determine the socio-economic, cultural and spiritual destiny of the state way. It is important to remember that a strong state is created in a well-managed environment.

It is true that man's inner world is so complex that his secrets are not even known to him. But finding a way to this complex human heart is necessary to save humanity. This need must be reflected in the professional competence of every leader, in the tools that guide people.

\section{CONCLUSION}

The development of science and technology will not bring happiness to humanity without radical changes in the socio-spiritual, cultural and moral spheres. Its influence as a powerful force for the future of humanity depends in many ways on the level of morality, cultural and spiritual maturity of the people, the degree of respect for universal values and the professional and personal competence of the leader.

\section{REFERENCES}

[1] Sh.M. Mirziyoyev's statement at the enlarged meeting of the Cabinet of Ministers on "The main results of socio-economic development of the country in 2016 and the most important directions of the economic program for 2017." T: uza.uz, 16.01.2017

[2] S.Y.Temurov: Theoretical bases of formation of professional competence in future mathematics teachers. Tashkent: Science and Technology-2014 p.44

[3] N.Muslimov, M.Usmonoboeva, D.Sayfurov, A.Turaev: Fundamentals of pedagogical competence and creativity. Tashkent-2015, p. 25

[4] N.A.Muslimov, K.M.Abdullayeva, O.A.Kuysinov, N.S.Gaipova, N.N.Karimova, M. Kadyrov: Technology of formation of professional competence of teachers of vocational education. Tashkent: Science and Technology-2013, p.32

[5] Jiyenbekovna, T. A. (2019). Formation of the system of increasing the qualification of teachers in Asian countries. European Journal of Research and Reflection in Educational Sciences: Special Issue 7 (10) pp 5861.http://www.idpublications.org/wp-content/uploads/2019/08/Full-Paper-FORMATION-OF-THESYSTEM-OF-INCREASING-THE-QUALIFICATION-OF-TEACHERS-IN-ASIAN-COUNTRIES.pdf

[6] Alfiya Zhienbekovna Turekeeva ., EDUCATIONAL ISSUES IN FOREIGN EXPERIENCE., ACADEMICIA: An International Multidisciplinary Research Journal ., Vol. 10, Issue 6, June 2020, http://dx.doi.org/10.5958/2249-7137.2020.00528.5

[7] Irgashevich, D. A. (2020). Development of national network (tas-ix). ACADEMICIA: An International Multidisciplinary Research Journal, 10(5), 144-151. Article http://dx.doi.org/10.5958/2249$\underline{7137.2020 .00254 .2}$ 